change of elements may take place; this, however, of course depends upon the amount of change which the actual mean motion may undergo, from the successive smaller perturbations of the next thirty years.

BORRELLY'S COMET OF DECEMEER 6.-Thus far it docs not appear that any orbit of the last comet discovered at Marseilles has been published. The following elements, founded on observations between Dec. 7 and 26, received from M. Stephan, Director of that Observatory, may therefore possess some interest :-Perihelion passage, Oct. 19,1874 , at $4 \mathrm{~h} .36 \mathrm{~m}$. Greenwich time; ascending node, $282^{\circ}$ I $2^{\prime} 49^{\prime \prime}$; distance of perihelion from node, counted on the orbit in the direction of motion, $15^{\circ} 23^{\prime} 34^{\prime \prime}$; inchination, $80^{\circ} 56^{\prime} 28^{\prime \prime}$; distance in perihelion, 04965 ; motion, retrograde. These elements bear no close resemblance to those of any previously computed comet.

\section{ON A PROBABLE CAUSE OF THE CHANGE OF THE COURSE OF THE AMÚ DARYA FROM THE CASPIAN TO THE ARAL*}

[F the central regions of Asia are really, as is surmised, the localities where the youth of the human race was passed, agriculture, aided by irrigation, has probably been practised from the earliest ages on the banks of the Oxus.

The description, in Herodotus, of the plain in Asia through which a mighty river called Aces ran and watered the lands of five nations inhabiting its banks, may possibly not apply to the Oxus valley, though the Chorasmians are specified as one of the five nations. But the passage clearly describes the distribution of the waters of the Aces for the purposes of cultivation, and it may with reason be inferred that the art of irrigation was in vogue in the Kharesmian oasis some two thousand years ago. However this may be, the Chinese traveller Hiouen-thsang speaks of Khiva, in the seventh century of our era, as forming but a narrow band on both banks of the Oxus; a clescription which does not admit of a doubt that the waters of the river were then employed in watering the land.

At the present day the Khanate of Khiva, as is well known, owes its fertility to the numerous canals of irrigation derived from the Amú, between Pitnak and Nukus. The heads of these artificial canals are kept open during the part of the year included between the months of May and November, and thus allow the summer or flood waters of the river, which pass into them, to be distributed over the land of the Khanate. As the volumes and velocities of the streams entering the several canals are less than that of the flood of the Amti, a deposition of silt, carried in suspension by the waters, takes place in these canals. For this, among other reasons, their heads are closed during the winter and early spring months, so as to allow of their rumning dry, and the deposited silt being then cleared, by manual labour, from their beds.

I am not aware that even a rough estimate has ever been made of the quantity of water thus diverted from the Amu, and passing into these canals, during the period of the yearly floods. It is clear, however, that the physical phenomena of the river must be sensibly affected by the abstraction of so large a body of water from its stream, and I will, therefore, make some attempt to arrive at an approximation to the truth on this head, though the data at my disposition are insufficient, and the conditions of the problem are such as render it difficult to attain to any great precision.

The land under cultivation in the Thanate is generally estimated at about two millions of acres; if we assume that the whole of this cultivation requires the constant use of water, about 40,000 cubic feet per second must be taken by the several canals from the river. It is perhaps true that many of the crops do not require more than partial irrigation, but, on the other hand, the population of about 400,000 souls, and the cattle of the Khanate, are entirely dependent on the river for their water supply. The excess, therefore, assigned for irrigation may be considered as absorbed by the people and by the cattle, and the estimate of 40,000 cubic feet per second may be allowed to stand for the present.

* Presented to the Imperial Geographical Society of Russia, December 4, 1874 ; read at the monthly meeting of the Society, December 16,1874 ;
A very rough calculation, founded on the scanty data to be found in Creneral Ivanien's pamphlet on Khiva, and made by me some four months ago, gave 30,000 cubic feet per second as the quantity of water diverted from the Amit by the irrigation canals. It is to be remarked, however, that the few dimensions given of these canals are merely founded on hearsay evidence, and are not the result of actual careful observation, and they refor, moreover, to the state of things which existed forty years ago. No correct estimate can be expected to be deduced from such confessedly general and incomplete information. It results, then, that the first estimatc of 40,000 cubic feet per second, founded on the known necessities of the land and its population, is probably nearer the truth than the second, which I derived from a perusal of General Ivanien's interesting pamphlet.

It has already been said that the heads of the canals remain open during the flood season of the Amu; the quantity of water, consequently, entering the canals, depends upon the height of the summer floods of the river, and will be greater as the level of the flood is higher, and will be less as that level is lower. But since a supply of about 40,000 cubic feet per second is a matter of actual necessity to the lives of the population of the Khanate, it is clear that the levels of the canal beds, at their heads, must be so adjusted as to provide for the entry of 40,000 cubic feet per second, even should the level of the Amú food be an exceptionally low one. It results, therefore, that in all years, except that of an exceptionally low flood, a much greater quantity of water than what is actually required for irrigation and for consumption by the population and by the cattle is diverted from the Amu, and passes by the irrigation canals of Khiva. Ivanien mentions that the excess of water passing by the canals during hish floods is allowed to flow into lakes and into the Doudon, Kunya Daryalik, and other old dry beds of the Amu, which thus act as safety-valves to the embankments and works belonging to the irrigated tract. The conclusion which may be drawn from the foregring is, that in most years there is a very great waste of water arising from the imperfect system of irrigation employed in Khiva. It is needless to enlarge on the magnitude of such an evil in a locality where water is an absolute necessity to prevent the advance of the surrounding desert. With a scientific system of irrigation, it is probable that an acreage of land equal to that at present cultivated on the banks of the Amu might be reclaimed from the desert, by precisely the same expenditure of water which now takes place.

The following table, which I have ventured to compile from the measurements and observations of the Amí Darya made by the officers of the expedition sent in 1874 , under the auspices of the Imperial Russian Geographical Society, will enable some idea to be formed of the waste of water which took place on several dates between the 23 rd of June and the Ioth of September of the year in question. The table shows, in cubic feet per second, the total discharge of the river, the portion of that discharge diverted by the irrigation canals, and the remaindier which passed Nukus. I must, however, remark that the quantities shuwn should be regarded as an approximation only to the truth.

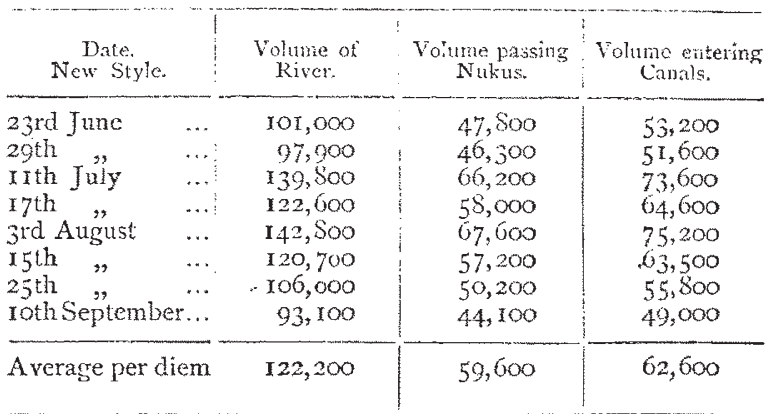

These figures show that in lieu of 40,000 cubic feet per second, which is the water supply estimated to be sufficient for the wants of the Khanate, the irrigation canals, between the 23 rd of June and the roth of September, 1874 , diverted, on an average, 62,600 cubic feet per second from the Amú Darya, or ten-nineteenths of the whole volume of the river.

Information does not yet exist which would allow more than a guess to be made of the volume of the low-water discharge of the Amú, but from what has been already stated, it follows that at Nukus there is a very much less difference between the 
volumes of the summer and winter discharges than there would be if the river were in a state of nature, and if a large portion of its flood-water were not diverted by man for the purposes of irrigation. This equalisation between the summer and winter discharges of the Amú, below the irrigated tract, has great sig. nificance, and has suggested to me a cause which may probably account for the change in the course of the river from the Caspian to the Aral. It is a matter of notoriety that the waters of the Amú carry in suspension an enormous quantity of mud and sand, and it is to the deposition, in its old bed, of this suspended matter, that I am inclined to think the change in the course of the river may with much probability be ascribed.

In speaking of the aqueous causes of the changes taking place on the surface of the earth, Sir Charles Lyell, in his "Princip!es of Geology," has made the following remarks on the transporting power of water. As they cannot be put in plainer and better language, and as they bear intimately on the theory $I$ have hazarded, I will quote them verbatim and in extenso:- "The force," he says, "of mountain torrents is easily understood ; but a question naturally arises, how the more tranquil rivers of the valleys and plains, flowing on comparatively level ground, can remove the prodigious burden which is discharged into them by their numerous tributaries, and by what means the are enabled to convey the whole mass to the sea. If they had not this removing power, their channels would be annually choked up, and the valleys of the lower country and plains at the base of mountain chains would be continually strewed over with frag. ments of rock and sterile sand. But this evil is prevented by a general law regulating the conduct of running water: thus, two equal streams do not, when united, occupy a bed of double sur-

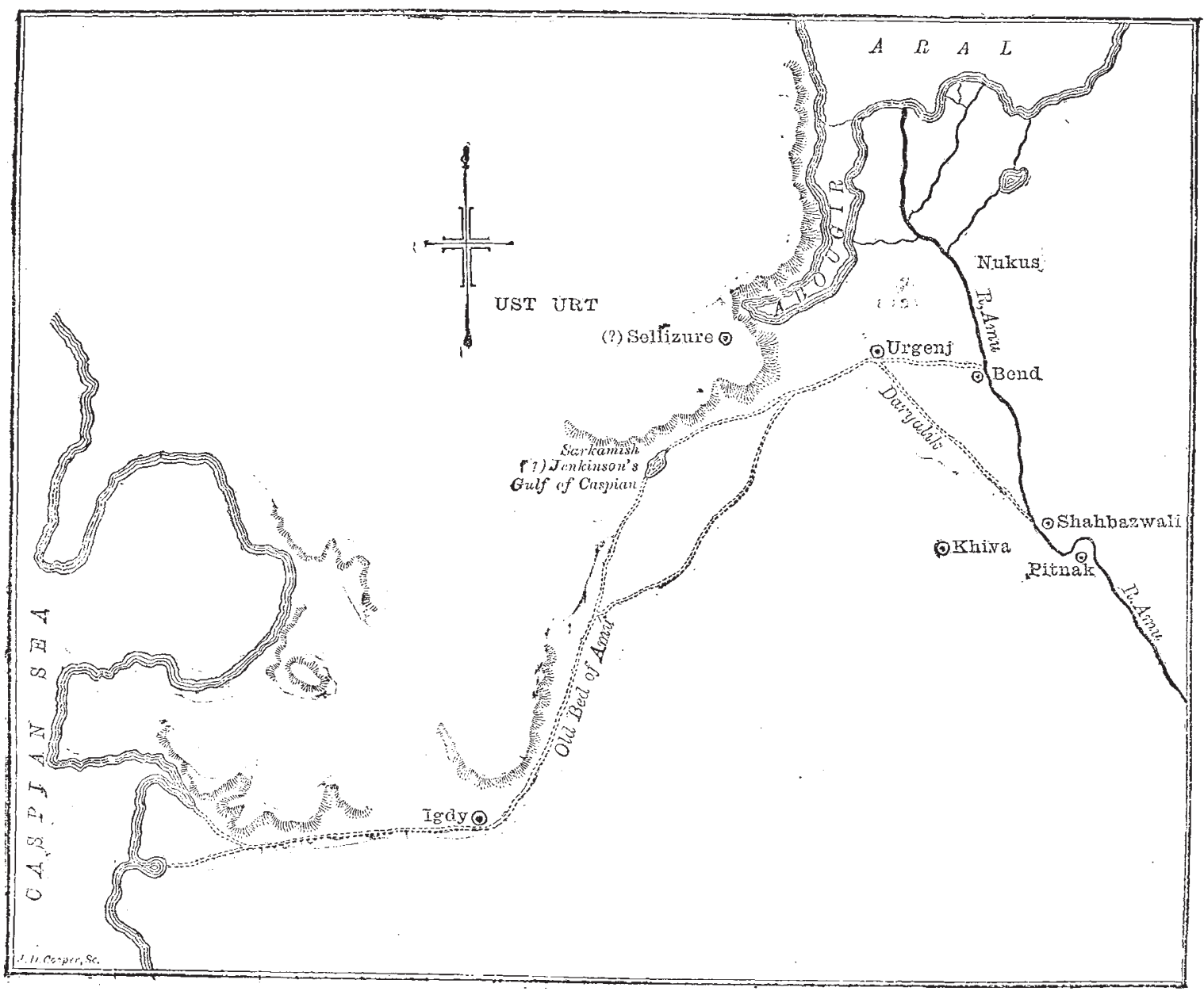

face. Nay, the width of the principal river, after the junction of a tributary, sometimes remains the same as before, or is even lessened. The cause of this apparent paradox was Iong ago explained by the Italian writers, who had studied the confluence of the Po and its feeders in the plains of Lombardy. The addition of a smaller river augments the velocity of the main stream often in the same proportion as it does the quantity of water. The cause of the greater velocity is, firstly, that after the union of two rivers, the water, in place of the friction of four shores, has only that of two to surmount; secondly, because the main body of the stream, being further distant from the banks, flows on with less interruption; and lastly, because a greater quantity of water, moving more swiftly, digs deeper into the river's bed. By this beautiful adjustment the water which drains the interior country is made continually to occupy less room as it approaches the sea, and thus the most valuable part of our continents, the rich deltas and great alluvial plains, are prevented from being constantly under water."

Now, if we apply these principles to the Amú Darya, it is manifest that, when it fell into the Caspian, the conditions of its flow were such that the volume and velocity of its summer or flood-stream were sufficiently great to clear its bed annually of the deposition of siit due to the smaller volume and velocity of its winter stream. The figures given in the table show that the volume of water passing Nukus on the Ioth of September was a little more than one-third only of the total discharge of the river on the 3 rd of Angust, on which date, it is probable, the Amú Darya reached its maximum height for 1874 . I am in. clined to think, from a consideration of the winter discharges which are recorded by Wood in his work on the Upper Oxus, 
that the minimum volume of water passing Nukus during the winter months of any year is not very much less than that which mssed the same point on the roth September, 1874 . However, it is impossible, in the present state of our information, to state with precision either the volume of discharge during the winter months, or the quantity of water required to pass during the summer, to scour out the deposits made in the bed of the Amú by the winter discharge. But those who are inclined to confide in the intelligent arrangements of nature, will have no difficulty in believing that these two volumes were in such a state of proportion as corrected the evils induced in the bed of the river by the luw velocity of the smaller of the two volumes, i.e. of the winter discharge of the Amú. Under such circumstances, the bed of the river would be undeteriorated, its course would remain constant, and its flow would continue int s the Caspian sea.

But immediately the volume and velocity of the summer or flood discharges of the Amú Darya were decreased by the action of defluent canals excavated for the irrigation of the lands of Khiva, the compensa ory arrangements of nature, which previously kept the river's bed clear, would be interfered with, and some portion of the silt deposited by the winter stream would remain unremoved. This evil would increase yearly, and the intensity of its action would be greater as the quantity of water diveried for inigation purposes became greater. A portion of the deposit might occasionally be removed by an accidentally high flood, but, eventually, a state of things would supervene in which the conditions of the Amú would present the precise converse of the state of adjustment described in Sir Charies Lyell's work; that is to say, bars and banks of sand would form in the course of the river, would be enlarged yearly, and would prevent it from flowing on to the Caspian. The most westerly point reached by the waters of the river would continually recede to the east, and they would become erratic while seeking an outlet by a slope steeper than that of their encumbered old bed.

Such is a tolerably concise description of what I conceive has actually occurred in the case of the Amu, and has caused the change of its flow into the Aral Sea; and it now remains to examine whether such facts as are known regarding the change and the existent state of things are in harmony with the theory I have ventured to hazard.

Abulgaze Khan, in his history of the Mogois and the Tartars, relates that in the early part of the sixteenth century "all the road from Urgenj as far as Abul Khan was covered with aouls, i.e. encampments of nomads; for the Amú Darya, after having passed under the walls of Urgenj, flowed to the foot of the eastern slope of Mount Abul Khan, whence the river turned to the south-west, to turn afterwards to the west, and empty itself at Ogourtclia into the Sea of Mazanderan. The two banks of the river as far as Ogourtcha presented a succession of cultivated lands, of vineyards and of orchards . . . All that country was at that ine very populous and in the must flourishing condition." In the early part of the sixteenth century, therefore, the Amú Darya fell into the Caspian, and irrigation, by means of its waters, was general along its banks from Urgenj as far as Abul Khan.

Anthony Jenkinson, the Englishman travelling from the Caspian eastwards in A.D. 1559 , arrived on the 5 th Uctober at what he called a "gulle of the Caspian Sea." Nere he found "the water very fresh and sweete." He continues: "Note that in times past there did fal into this gulle the great river Oxus, which hath his springs in the mountains of Parapomisus, in India, and now cometh not so far, but falleth into another river called Ardok, which runneth towards the north. "The "very fresh and sweete water" found by Jenkinson could only have been brought l,y a flood, or have forced its way either by a channel or by filtration through the sand-banks into the old bed of the Oxus to the spot in question. At the date mentioned, therefore, by Jen. kinson, some of the waters of the Amí Darya could still find their way to the Caspian, and the opening of the new course into Ardok, and the closing of the old course, must have been circumstances of tolerably recent occurrence.

Jenkinson continues his narrative thus:-_We, having refreshed ourselves at the forsaid gulfe, departed thence the 4 day of October (either this or his first date, therefore, is a mistake), and the seventh day arrired at a Castle called Sellizure. . . The Castle of Sellizure is situated upon a high hill. . . The south part of this Castle is lower land, but very fruitful, where grow many good fruites. . . the water that serveth all that country is drawen by ditches out of the river Oxus, unto the great distruction of the said river, for which cause it falleth not into the Caspian Sea as it hath done in times past, and in short time, all that land is like to be distroied, and to become a wilderness for want of water, when the river of Oxus shall fall."

This apprehension was soon to be realised, for Abulgazee relates, in the work already quoted from, that thirly years before his birth, ie. in A.D. 1575, the Amú Darya found a passage for itself into tha Sea of Aral; a circum nuce which changed the environs of Urgrenj into a desert by depriving them of the water nectssary for the irrigation of the soil.

From the foregoing extracts we learn that, commencing with some year early in the sixteenth century, the stream of the Amú Darya, year after year, fell short of reaching as far to the west as it formerly did, until in A.D I 575 the new channel into the Ara conveyed the whole of the waters which remained after the irrigation of the lands of the Khanate lying on th $\approx$ ccurse of the river above Urgenj had been provided for.

As regards the actual condition of the old and present beds of the Anu Darya, the levelling operations carried out in 1873 and 1874 afford the following data:-

\begin{tabular}{|c|c|c|c|c|c|c|}
\hline Ieig & Aral & & & e Caspia & 250 & les \\
\hline " & Igdy & * & & Caspian & 190 & \\
\hline 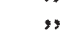 & Nukus & & & Aral. & 60 & \\
\hline & Nukus &. & & Caspian & $3: 0$ & \\
\hline & Bend & & & Aral. & 70 & \\
\hline & Bend & & & Caspian & 320 & \\
\hline 9 & Shahb & azwa & & Aral. & 140 & \\
\hline & Shahbo & azwa & & Caspian & 390 & \\
\hline
\end{tabular}

Distance along old Amú from Caspian to Igdy . . 200 miles.

\begin{tabular}{|c|c|c|c|c|c|c|c|}
\hline & & & & & & & \\
\hline 3 & $"$ & " & & lgdy. & - & 274 & ", \\
\hline$"$ & $"$ & ", & Urgenj & "Bend & - & 43 & " \\
\hline ", & , & $"$ & Urgenj & "Shahbo & azwal & 133 & ") \\
\hline &, & , & Bend. & „Nukus & . & 17 & \\
\hline
\end{tabular}

The foregoing distances are taken along the meanders of the bed.

Hence the slope per mile from the Caspian . to Igdy. is I I i

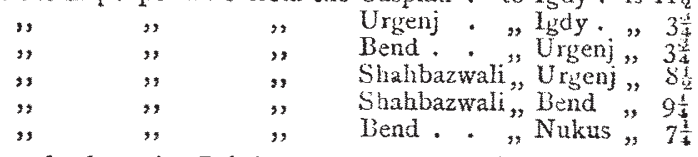

From the foregoing $I$ infer Urgenj to be $50 \frac{1}{\mathrm{ft}}$, above Aral, and $306:$. $t$, above the Caspian.

The following are the conclusions $I$ draw from the foregoing data:-

1. That the oid bed between Urgenj and Igdy, having the abnormally small slope of $3 \frac{3}{4} \mathrm{in}$. per mile, has probably been raised by the deposit of silt carried by the waters of the river.

2. That the bed of the Kunya Daryalik, which commences opposite Shahbazwali, having a slope of $8 \frac{1}{2}$ in. per mile above Urgenj, discharged a larger body of water than the bed below that place. The difference of the discharges must have been disposed of in irrigation, and the abstraction of water from the Kunya Daryalik was the cause of the silt deposited in the bed of the river below Urgenj, as well as of that in the Kunya Daryalik itself.

3. The bed of Kunya Daryalik having a slope of $8 \frac{1}{2}$ in. per mile, while that of the present river, downwards to Bend, from the head of the Kunya Daryalk, has a slope of 9 t in., it follows, that the slope of the old course must have been flattened from something steeper than $9 \frac{1}{4}$ in. per mile to 81 in. per mile; otherwise, the waters of the river could have never passed by the Kunya Daryalik towards Urgenj.

4. The water passing along the old Amu being headed back by the deposition of silt in the old bed of the river, becane erratic during floods, and found an outlet by the Ardok channel, which eventually carried all the waters of the Ama Darya towards Nulius.

5. The small difference of slope per mile of the beds of the Kunya Daryalik, and the present Amú Darya, explains the tendency of the flood waters to escape from the river, and the necessity of the dams found along the old course. And since the slope of the bed of the Amú Darya down to Bend is $94^{\frac{1}{1}}$ in. per mile, while that from Bend to Nukus is $7 \frac{1}{4}$, there must always be a tendency, during floods, for the waters to be headed back at Bend, and so to seek an escape by the Loudon channel, across the mouth of which a dam has been constructed to prevent such an occurrence. The condition of the bed of the Amú Darya, from where the irrigation canals commence, down to Bend, fully accords with the theory of the change of the course of the river developed in this note. Descending from the point indicated, the bed of the river is more and more encumbered 
with shoals, until in the reach where Bend is situated, and where the maximum volume has been abstracted for purposes of irrigation, the entire breadth of the Amú Darya is obstructed by a mass of sandbanks intersected by narrow and tortuous channels.

It appears, then, that such information as we have, regarding the change and the existent conditions of the old and new courses of the Amú Darya, presents a picture precisely the converse of that delineated in and quoted from Sir Charles Lyell's work. In lieu of a constant increase to the transporting capacity of the waters of the river, we see that in the Amu Darya such is replaced by a constantly diminishing transporting power, and that the old bed has been filled up and destroyed by the deposition of silt. This deposition of silt and deterioration of the bed can only have been caused by the abstraction of its waters for irrigation. Whether other circumstances assisted the consequent change of the flow of the Amu Darya is a question it is not my purpose to examine in this place. Fnough has, I would submit, been adduced to show that the practice of irrigation, as con. ducted on the banks of the Amu Darya, produces phenomena whose action furnishes a probable explanation of a very curious and interesting geographical problem.

Herbert WOOD

\section{TIIE PARIS INTERNATIONAL CONGRESS OF} GEOGRAPHICAL SCIENCE

THE meeting of the International Congress, of which we published the programme a few months ago (vol. $x$. p. 267), has been postponed, owing to the large number of demands from foreign parts for room in the Exhibition. It will not take place in the beginning of spring as intended orginally, but will be opened on the ist of August, perhaps by the President of the Republic, who seems to be deeply interested in the success of the enterprise. It will be held in the Pavillon de Flore. This magnificent building was left unfinished when the Empire was upset, and could not be burned by the Communists, as the woodwork had not been bersun. It is now being decorated most tastefully, and will be inaugurated by the Congressionists.

An exhibition will also take place in the Pavillon de Flore and Orangerie situated close to the Place de la Concorde. All the Terrace du ford de 1'Eau, from the Yavilion de Flore to the Orangerie, will torm part of the Exhibition. Temporary sheds of every cescription will be constructed in that splendid situation along the banks of the seine and under the four rows of lofty trees. The coup $d$ 'cil will be splendid, and is sure to attract an immense number of spectators. The Exhibition will be opened on the Igth of July, and will last until the 4th of August. A very large number of gentleinen of ali countries liave been appointed members of the honorary committee. The president of the Congress is M. Delesse, a French engineer in the mining service, and a great geologist. $M$. Delesse is now the president of the Central Committee of the Geographical Society. Up to the present moment the vice-president has not been elected.

The Exhibition and Congress, as we formerly notified, have been divided into seven different groups: (I) Mathematical ; (2) Hydrographical ; (3) Physical ; (4) Historical ; (5) Economical ; (6) Didactic ; (7) Travels.

A programme of 123 questions has been published, and all these, as far as possible, will be discussed by the members of the Congress. The principal questions will be found in the article referred to.

ON THE ALTERATION OF THE NOTE OF RAILWAYWHISTLESIN TRAINS MEETING EACH OTHER

T AM not aware whether the following explanation of this curious acoustical phenomenon has ever appeared in print; if it has, it will, I think, bear repetition, as offcring an interesting illustration of some of the laws of propagation of undulations through aërial media.
If two railway trains mect and pass each other at tolerable speed, and the driver of one of them is sounding his whistle, any person in the other train accustomed to music will notice that the moment the whistle passes him its note will be lowered in pitch in a marked degree.

It was at first supposed that, at the time of passing, the driver lowered his whistle intentionally, as a salute to the other train (like "dipping the ensign" at sea), but this was found not to be the fact, the driver himself being unconscious of any change. I believe the true explanation was first given by Mr. Scott Russell, but I do not know when or where.

It is an exactly parallel case to one which has recently attracted attention in astronomy, namely, the evidence afforded by the change in position of certain spectral lines, owing to the vapours which produce them approaching or receding from the observer. The explanation of this will be familiar to most of the readers of NATURE, and I have only to apply it to the case in question.

Every musical note propagates aërial waves succeeding each other with a known rapidity, corresponding to the pitch of the note; the higher the pitch, the greater the rapidity of succession of the waves, and vice versâ. Now, when a person advances to meet these waves, more of them will pass him in a given time than if he stood still, on the same principle that if a man meets a file of soldiers on march, more men will pass him per minute than if he were stationary. Thus the apparently increased rapidity of the waves will give him the impression of a sharper note.

On the other hand, when the trains have passed each other, the listener will be moving in the same direction as the sound-waves, and consequently a less number will pass him in a given time, causing the note to appear flatter.

The sum of these effects will be the sudden drop of the pitch of the note at the moment the listener passes the whistle.

We may reduce the effect to numerical calculation, premising that, in order to simplify the reasoning, we will suppose the source of the sound to be stationary, and the observer to move towards it with a given velocity.

Let $n=$ number of sound-waves propagated by the given note per second; and let $n_{1}=$ the number which the listener will gain by his advance in the same time, which is the number he would pass by lis ozon proper motion if the waves were standing still.

Then the effective number of waves per second which will meet his ear will be $=n+n_{1}$, this number determining the pitch of the note be hears. This may be called (by an astronomical analogy) the apparent pitch, as distinguished from the true pitch.

To find the value of $n_{1}$, let $\mathrm{L}=$ the length of the soundwave $\left(=\frac{V}{n}\right.$ where $V=$ velocity of sound in feet per second). Then, if $v=$ velocity of motion of the listener he would pass, by his own proper motion, $\frac{\tau}{L}$ waves per second; whence $z_{1}=\frac{v}{L}=\frac{n z}{V}$.

Hence the apparent pitch of the note is what will correspond to the number of vibrations

$$
=n+\frac{n v}{V}=n\left(\mathrm{x}+\frac{v}{V}\right)
$$

But we may simplify this by applying the harmonic principle, that a musical interval is measured by the ratio of the vibration numbers of its higher and lower limiting sounds. Let therefore $\delta=$ the interval between the real and the apparent sound ; then

$$
\delta=\frac{n\left(\mathrm{x}+\frac{\nu}{V}\right)}{n}
$$

